\title{
A Phenomenal Conservatist Response to Proper Functionalism
}

\section{Logan Paul Gage and Blake McAllister}

We must begin by noting that we endorse Reformed Epistemology, defined by McNabb as the claim "that a subject $S$ 's religious belief can be justified or warranted apart from argumentation." This is, of course, because we think that subjects are justified in believing propositions that seem true to them so long as they lack defeaters (regardless of whether they are capable of mounting arguments for such propositions-let alone arguments that others would find satisfactory). McNabb, on the other hand, supports the thesis of Reformed Epistemology by defending a Plantingian proper functionalist account of warrant. And it is toward this Plantingian version of Reformed Epistemology that we will offer two concerns. First, we question the sufficiency of the proper functionalist account of warrant. Second, we argue that even if this account of warrant were satisfactory, Phenomenal Conservatism retains an important dialectical advantage over this account.

\section{§1 An Objection to Proper Functionalism}

McNabb and Plantinga's proper functionalist account of warrant (warrant being understood as whatever turns true belief into knowledge) claims that $S$ 's belief that $p$ is warranted if and only if (i) $S$ 's belief that $p$ results 
from a properly functioning cognitive system, (ii) the cognitive system is operating in a similar environment to the one for which it was designed, (iii) the cognitive system is aimed at the production of true beliefs, and (iv) the system's design plan is such that there is a high objective probability that $p$ is true. We think, however, that a subject could have a true belief that $p$ meet conditions $\mathrm{i}-\mathrm{iv}$, and yet not know that $p$. That is, we think conditions $\mathrm{i}-\mathrm{iv}$ insufficient for warrant.

Imagine a subject named Skyler. Skyler has a newfound belief in God's existence. The experience that triggered Skyler's theistic belief was, oddly enough, the observing of yard kitsch-in particular, those iconic plastic pink flamingos designed by Don Featherstone in 1957. To Skyler, there is nothing about these flamingos that indicates God's existence. This new belief feels like a random hunch to her. Let us add that Skyler took a psychedelic drug earlier that she knows can induce random beliefs of just this sort. From Skyler's perspective, there is simply no indication that her belief is likely to be true. Realizing this, Skyler tries to stop believing but finds she cannot rid herself of this apparently baseless conviction. Despite all of this, Skyler's belief was not produced by the drug, nor was it entirely random. In actual fact, God designed Skyler to form an irresistible belief in His existence whenever she encounters that precise sort of yard kitsch. Thus, Skyler's belief meets conditions i-iv and, according to Proper Functionalism, is thereby warranted. ${ }^{1}$ But, contra Proper Functionalism, Skyler's belief does not seem to constitute knowledge that God exists.

What is lacking is some indication from Skyler's own perspective that her belief is true. There needs to be some intelligible connection between the content of her belief and that on which it is based. Skyler's belief, however, is based on an experience whose content bears no discernible relation to God's existence. What we are proposing is that a fifth condition is necessary for warrant-namely, that the belief is based on a body of evidence that, on-balance, indicates the truth of that belief from the first-person perspective. A belief must result from proper functioning and be based on good evidence in order to constitute knowledge.

Phenomenal Conservatism explains how this fifth condition can be met by basic beliefs, even though they are not based on evidence from other propositions. On Phenomenal Conservatism, the subject's seeming that $p$ gives the subject evidence for $p$. Thus, if it seems to you that the Steelers just scored a touchdown, then you have some evidence that the Steelers just scored a touchdown. Assuming you have no evidence to oppose this, a belief based on that seeming will satisfy the fifth condition on warrant. The key is that 
the content of your belief (unlike Skyler's) is intelligibly connected to the experience on which it is based.

Now, on Plantinga's model, the content of the triggering experience doesn't ultimately matter. His SD is a simple "input-output device" in which certain experiences are designed to trigger theistic belief. ${ }^{2}$ Given the right design plan, then, any experience could lend warrant to a theistic belief. It is telling, however, that the stock Plantingian examples are of starry skies, majestic mountains, and tiny flowers. These experiences all seem to bear an intelligible connection to theistic belief: such beauty and apparent design evidence (at least weakly) an intelligent designer. We suspect that, had Plantinga chosen yard kitsch as his go-to example, fewer people would have intuited that the resulting beliefs were warranted. Instead, he chose experiences that bear an intelligible connection to God, allowing the fifth condition on warrant to go unnoticed.

\section{§2 A Dialectical Advantage}

Even if our first critique is mistaken, and the proper functionalist account of warrant does not need a fifth condition, there remains a weakness in McNabb's defense of Reformed Epistemology. Reformed Epistemology, once again, is to be understood as the claim that certain religious beliefs can be warranted or justified apart from argumentation.

McNabb's defense of Proper Functionalism, if successful, establishes the following conditional:

(1) If God exists and has given us a sensus divinitatis, then theistic belief can be warranted apart from argumentation.

Notice that this conditional does not assert the truth of Reformed Epistemology. It says that Reformed Epistemology is true if we have a Godgiven $S D$. Defending this conditional was useful for Plantinga's purpose: to defend religious belief against the claim that it is epistemically subpar even if God exists. For, in light of this conditional, you cannot show that theistic belief is unwarranted without showing that it is false. McNabb, on the other hand, is trying to argue that Reformed Epistemology is true. Thus, to complete his defense, $\mathrm{McNabb}$ needs to provide evidence for both (i) that God exists and (ii) that God gave us an $S D .{ }^{3}$ We think that the case for (1) is strong and that there is much to be said for (2), but until he provides evidence for these 
claims, McNabb has not established Reformed Epistemology's assertion that theistic belief can be warranted without arguments.

This problem highlights a serious dialectical advantage of the Phenomenal Conservative approach. On Phenomenal Conservatism, even an atheist could agree that theistic beliefs are sometimes noninferentially justified. ${ }^{4}$ If it seems to someone that God exists, and she does not possess lasting defeaters for these strong seemings (challenges arise, we can imagine, but reflection repeatedly assuages her doubts), then Phenomenal Conservatism says that her theistic belief is justified without argumentation, even if God does not exist. Accordingly, Phenomenal Conservatives can argue for Reformed Epistemology without the burden of establishing God's existence (or His bestowal of a special religious faculty). ${ }^{5}$ If, however, we seek to support Reformed Epistemology by an appeal to Proper Functionalism, then it becomes incumbent to argue that God exists and that He is likely to give us something like the $S D$. For on current proper functionalist models, atheists should not agree that religious beliefs can be warranted apart from arguments. ${ }^{6}$ Phenomenal Conservatism, therefore, makes it considerably easier to argue for Reformed Epistemology than McNabb's Proper Functionalist approach.

\section{Notes}

1. Notice that Skyler's knowledge that her theistic belief may be the result of a psychedelic drug does not constitute a defeater given Proper Functionalism. This is because Skyler's continued belief in light of that knowledge is a part of the reliable, truth-aimed design plan given to her by God.

2. Plantinga, Warranted Christian Belief, 174-5.

3. He may also need to show that our typical theistic beliefs are actually the result of the sensus divinitatis rather than some other cognitive process.

4. You'll notice that Phenomenal Conservatism is about justification, not warrant. This shift in focus is part of why Phenomenal Conservatism possesses the dialectical advantaged spelled out here.

5. To see this approach in action, see McAllister and Dougherty, "Reforming Reformed Epistemology."

6. Plantinga states that if God does not exist, then belief in His existence is probably not warranted. See Plantinga, Warranted Christian Belief; however, if Proper Functionalists adopt the model of the sensus divinitatis developed in McAllister and Dougherty's "Reforming Reformed 
Epistemology" then they might be able to maintain that religious beliefs have some degree of warrant-albeit a degree falling sort of that which is required for knowledge-even if God does not exist. See footnote 21 of the aforementioned article. 